\title{
Climate change: an opportunity for health promotion practitioners?
}

\author{
Philippe Chastonay $\cdot$ Ursula Zybach $\cdot$ Jean Simos • \\ Thomas Mattig
}

Published online: 2 July 2015

(C) Swiss School of Public Health 2015

At present climate change is recognized as a major threat to human health by the world's international organizations. Some experts consider that "the predicted effects of extreme global heating (about $4{ }^{\circ} \mathrm{C}$ above its pre-industrial values by 2100) would probably exceed the limits of human adaptation" (Woodward 2014). On the short run, data suggest that climate change dramatically increases health inequities affecting most fragile populations mainly through its effects on the social determinants of health. There is need for action. And action has to be coordinated and collaborative (WHO 2014).

Health professionals might play a central role in the process. Especially health promotion practitioners might be key persons. Why "especially" health promotion practitioners? For several reasons one might argue.

- First, it is their keen (or are we wrong?) understanding of the Ottawa Charter (WHO 1986) on health promotion that makes them natural actors concerning climate change and health. As stated in the Charter "any health promotion strategy should include the protection of the natural environmental and conservation of resources",

This editorial is part of the special issue "Driving the Best Science to Meet Global Health Challenges" edited on the occasion of the 9th European Congress on Tropical Medicine and International Health 2015.

P. Chastonay $(\bowtie) \cdot$ U. Zybach

Public Health Switzerland, Bern, Switzerland

e-mail: philippe.chastonay@unige.ch

J. Simos

Institute of Global Health, University of Geneva, Geneva,

Switzerland

T. Mattig

Health Promotion Switzerland, Bern, Switzerland health promotion is conceptually on line with the ecological framework proposing sustainable solutions to present and future environmental challenges. The Charter also puts health on the agenda of policy makers in all sectors and at all levels, allowing co-benefits for health through measures against climate change.

- Second, the 2009 Galway Consensus Conference defined core competencies of and core values for professionals in health promotion to "meet the global public health challenges of the 21 st century" (Allegrante et al. 2009), including the need for environmental sustainability and climate change-related health problems.

- Third, the 20th IUHPE World Conference on Health Promotion in 2010-Health, Equity and Sustainable Development—-specifically addressed "ways to achieve healthy people on a healthy planet" (IUHPE 2010), "A step in the right direction to galvanize support and mobilize the health promotion workforce" for some experts (Patrick et al. 2012).

- Fourth, the 2013 International Conference-FranceQuebec-Africa: Adaptation to climate change and public health, can we do better?-calls for "actions to be taken to develop innovative solutions to reduce climate change risks and impacts on public health" (Conférence France-Québec-Afrique 2013), including the transformation of cities (e.g., greening cities, fight against heat islands, install reflective white roofs, etc.). The 2014 Athens Declaration for Healthy Cities hints into the same direction "the quality of urban life requires our urgent action to combat climate change and how it affects health" (WHO-Europe 2014) reaffirming the fundamental values of the Ottawa Charter. Again health promotion practitioners seem key in implementing such actions. 
- Finally, health promotion practitioners have experience (or are we wrong again?) with the multistep approach recommended by Gill and Stott (2009) for effective and efficient action in the field of climate change and health, i.e., they know how:

- to inform the population and the politicians about health risks related to inaction and to health benefits related to action;

- to affirm their convictions, showing leadership through action within their institution, their community and society at large;

- to advocate for core values and evidence-based decisions to impact on the political agenda;

- To innovate, because creative action might favor change of individual behaviors, political decisions, societal norms;

- To disseminate the message through networks and new communication channels.

In this crucial matter for the health and wellbeing of mankind related to climate change, the World Health Organization must take the lead and show the way to go, namely in mobilizing the huge potential of the health workforce worldwide. This will allow to further implement the WHO work plan on climate change and health endorsed in 2009 by the World Health Assembly including advocacy, (i.e., raise awareness), partnership (i.e., coordinate actions), science and evidence (i.e., develop a global research agenda), strengthen health systems (i.e., build capacity). Taking up the last point "building capacity", health promotion practitioners are an ideal target. Yet, we ignore health promotion practitioners' “opinions, motivation and perception of the importance of addressing climate change" (Sulda et al. 2010).

But is it reasonable to think that motivated health promotion practitioners could actually make any difference? We would think so, having in mind this African proverb cited by Haines (2009): "If you think you are too small to make a difference, try sleeping in a closed room with a mosquito".
As Dr. Maria Neira (2014) of WHO expressed it: “The impact of climate change on human health is, indeed, alarming. .... Yet, I am optimistic.... It is time now to translate knowledge into action".

Are health promotion practitioners ready for it?

\section{References}

Allegrante J, Barry M, Auld E, Lamarre M, Taub A (2009) Toward international collaboration on credentialing in health promotion and health education: the Galway Consensus Conference. Health Educ Behav 36(3):427-438

Conférence France-Québec-Afrique (2013) Adaptation aux changements climatiques et santé publique : pouvons-nous mieux faire? Québec. http://www.monclimatmasante.qc.ca/conferenceadaptation-changement-climatique-et-sante-publique.aspx

Gill M, Stott R (2009) Leadership: how to influence national and international policy. In: Griffiths J, Rao M, Adshead F, Thorpe A (eds) The health practitioner's guide to climate change. Diagnosis and cure. Earthscan, New York, pp 119-153

Haines A (2009) Introduction. In: Griffiths J, Rao M, Adshead F, Thorpe A (eds) The health practitioner's guide to climate change. Diagnosis and cure. Earthscan, Sterling, VA, pp XVIII$\mathrm{XX}$

IUHPE (2010) The 20th IUHPE World Conference on Health Promotion. Health, Equity and Sustainable Development 11-15 July 2010, Geneva, Switzerland. http://www.enwhp.org/ fileadmin/downloads/Upcoming_Events/Geneva2010.pdf

Neira M (2014) Climate change: an opportunity for public health. WHO Media Centre; http://www.who.int/mediacentre/ commentaries/climate-change/en/

Patrick R, Capetola T, Townsend M, Nuttman S (2012) Health promotion and climate change: exploring the core competencies required for action. Health Promot Int 27(4):475-485

Sulda H, Coveney J, Bentley M (2010) An investigation of the ways in which public health nutrition policy and practices can address climate change. Public Health Nutrition 13(3):304-313

WHO (World Health Organization (1986) The Ottawa Charter for Health Promotion. Ottawa, Canada: First International Conference on Health Promotion

WHO (World Health Organization) (2014) Climate change and health. WHO Fact sheet $N^{\circ} 266$. Reviewed August 2014

WHO-Europe (2014) Athens Declaration for Healthy Cities. http:// www.euro.who.int/_data/assets/pdf_file/0007/90664/E93730. pdf?ua $=1$

Woodward A (2014) Bull World Health Organ 92(11):774 